\title{
Zinc toxicosis in a dog secondary to prolonged zinc oxide ingestion
}

\author{
Jia Wen Siow* \\ AEC Adelaide, 102 Magill Road, Norwood South Australia 5067, Australia
}

\begin{abstract}
Zinc toxicosis is commonly associated with ingestion of metallic zinc objects. This report documents an uncommon presentation of zinc toxicosis, secondary to prolonged ingestion of a zinc oxide cream. A $5.6 \mathrm{~kg}$ 6-year-old ovariohysterectomised female Poodle cross presented as a transfer to an emergency practice for severe anaemia, pigmenturia, weakness, and inappetence. She had a history of vomiting and nine days of diarrhoea. Amongst other supportive treatments, a zinc oxide cream had been applied to her hind end due to severe diarrhoea scalding, and in hindsight, the owners realised she had ingested large quantities of this cream. She developed a severe Heinz body haemolytic anaemia, along with spherocytosis, left-shift neutrophilia, prolonged activated partial thromboplastin time, and mildly elevated blood urea nitrogen. The serum zinc concentration was markedly elevated. She was treated supportively and made a full recovery. This case illustrates the importance of a thorough medical history. Zinc toxicosis can have a good prognosis when diagnosed and treated promptly.
\end{abstract}

Keywords: Canine, Haemolytic anaemia, Heinz bodies, Toxicosis, Zinc.

\section{Introduction}

Zinc toxicosis appears to be most commonly associated with ingestion of metallic zinc objects, including pennies minted in the United States after 1982, pennies minted in Canada between 1997 to 1999, Euro cents, toys, identification tags, galvanised products, nuts and bolts, garland, and even toilet paper holders (Torrance and Fulton, 1987; Latimer et al., 1989; Luttgen et al., 1990; Norman et al., 1990; Robinette, 1990; Shaw et al., 1991; Gandini et al., 2002; Mikszewski et al., 2003; Borst et al., 2004; Volmer et al., 2004; Bexfield et al., 2007; Gurnee and Drobatz, 2007; Weingart and Kohn, 2009; Adam et al., 2011; Clancey and Murphy, 2012; Blundell and Adam, 2013; Bischoff et al., 2017).

This report documents a case of zinc toxicosis resulting from ingestion of a zinc oxide cream. Less commonly, toxicosis is associated with topical zinc oxide preparations when dogs chew whole tubes, or ingest excessive amounts applied to the skin over a period of time (Robinette, 1990; Inns, 1995; Welch, 2002). Preparations include nappy rash creams, sunscreen lotion, and shampoos (Robinette, 1990; Welch, 2002). Anecdotally, nappy rash creams are often used to treat diarrhoea scalding, as occurred in the current case. Zinc oxide is a strong gastric irritant, so most ingestions result only in self-limiting vomiting and/or diarrhoea that do not require any treatment (Robinette, 1990; Welch, 2002).

\section{History and clinical findings}

\section{Case Details}

A $5.6 \mathrm{~kg}$ 6-year-old ovariohysterectomised female Poodle cross presented as a referral to an emergency practice for severe anaemia, pigmenturia, weakness, and inappetence. Nine days prior to presentation, the dog was taken to a local veterinarian for restlessness and scooting after a visit to the groomers - there, her tail base and perineum were markedly erythematous, and she was prescribed prednisolone and a mometasone cream. Subsequently, she vomited and developed diarrhoea, and was taken an emergency practice. There, buprenorphine and maropitant were administered, and she was prescribed cephalexin and Sudocrem ${ }^{\circledR}$ (Teva Pharmaceutical Industries). The prednisolone and mometasone cream were stopped. Two days later, she appeared painful again and the diarrhoea was continuing. She was taken to her regular veterinarian and received a buprenorphine injection, and was prescribed Neocort ${ }^{\circledR}$ (Troy Laboratories) and metronidazole in addition to the Sudocrem ${ }^{\circledR}$ and cephalexin. On the day prior to presentation, she became inappetent. On the morning of presentation, she was found at home collapsed and having passed red coloured urine. She was immediately taken to her referring veterinary practice. Blood was collected for haematology and biochemistry with an external laboratory. Her in-house haematocrit was $18 \%$ (reference range 41-58\%). She was stabilised with intravenous fluid therapy, and received $1 \mathrm{~g}$ sucralfate orally and $3 \mathrm{mg}$ dexamethasone intravenously for suspected immune-mediated haemolytic anaemia before transfer to the emergency practice on the same day.

She had no history of known access to toxins, including onion and garlic, and was not an indiscriminate eater. 
On arrival to the emergency practice, she was dull and tetraparetic. She was tachycardic with a heart rate of 192 beats per minute (reference range 70-120 beats per minute), and tachypnoeic with a respiratory rate of 40 breaths per minute (reference range 18-34 breaths per minute). Her mucous membranes were pale pink and tacky.

A haematocrit and coagulation profile were performed whilst awaiting the external laboratory results. The haematocrit was $10 \%$ (reference range $41-58 \%$ ) with a total protein of $64 \mathrm{~g} / \mathrm{L}$ (reference range $59-78 \mathrm{~g} / \mathrm{L}$ ), and markedly haemolysed serum. The activated partial thromboplastin time was prolonged at 168.1 seconds (reference range 75-105 seconds), and prothrombin time normal at 18.4 seconds (reference range 14-19 seconds).

Haematology (Table 1) showed a marked regenerative anaemia with frequent spherocytes and Heinz bodies. Also of note was a moderate left-shift neutrophilia.

Table 1. Haematology results from an external laboratory on the day of presentation.

\begin{tabular}{|c|c|c|}
\hline Parameter & Value & Reference Range \\
\hline Haematocrit (L/L) & 0.17 & $0.35-0.58$ \\
\hline Haemoglobin $(g / L)$ & 51 & $100-206$ \\
\hline $\begin{array}{l}\text { Mean Corpuscular } \\
\text { Haemoglobin (pg) }\end{array}$ & 28 & $21-26$ \\
\hline $\begin{array}{l}\text { Mean Corpuscular } \\
\text { Haemoglobin } \\
\text { Concentration }(\mathrm{g} / \mathrm{L})\end{array}$ & 300 & $310-360$ \\
\hline $\begin{array}{l}\text { Mean Corpuscular } \\
\text { Volume (fL) }\end{array}$ & 94 & $64-76$ \\
\hline $\begin{array}{l}\text { Red Blood Cell (RBC) } \\
\left(\times 10^{12} / \mathrm{L}\right)\end{array}$ & 1.8 & $4.9-8.2$ \\
\hline $\begin{array}{l}\text { Absolute Reticulocyte } \\
\text { Count }\left(\times 10^{9} / \mathrm{L}\right)\end{array}$ & 144 & $10-110$ \\
\hline$\%$ Reticulocyte (\%) & 8 & $0.0-1.5$ \\
\hline Nucleated RBCs & 6 per $100 \mathrm{WBC}$ & \\
\hline Platelet Count $\left(\times 10^{9} / \mathrm{L}\right)$ & 304 & $200-500$ \\
\hline $\begin{array}{l}\text { White Blood Cell } \\
\text { (WBC) }\left(\times 10^{9} / \mathrm{L}\right)\end{array}$ & 37.1 & $4.5-17.0$ \\
\hline Lymphocytes $\left(\mathrm{x} 10^{9} / \mathrm{L}\right)$ & 0.7 & $0.9-3.5$ \\
\hline Monocytes (x109/L) & 1.9 & $0.0-1.1$ \\
\hline Neutrophils $\left(\times 10^{9} / \mathrm{L}\right)$ & 31.9 & $3.5-12.0$ \\
\hline $\begin{array}{l}\text { Band Neutrophils } \\
\left(\mathrm{x} 10^{9} / \mathrm{L}\right)\end{array}$ & 2.2 & $0.0-0.2$ \\
\hline Eosinophils $\left(\times 10^{9} / \mathrm{L}\right)$ & 0.4 & $0.0-1.4$ \\
\hline Basophils $\left(\times 10^{9} / \mathrm{L}\right)$ & 0.0 & $0.0-0.1$ \\
\hline Blood Smear & \multicolumn{2}{|c|}{$\begin{array}{l}\text { Moderate anisocytosis } \\
\text { Moderate polychromasia } \\
\text { Moderate spherocytosis } \\
\text { Moderate numbers of Heinz bodies } \\
\text { Mild toxic change }\end{array}$} \\
\hline
\end{tabular}

Serum biochemistry (Table 2) demonstrated mild elevations in alanine aminotransferase, aspartate transaminase, creatine kinase and blood urea nitrogen.
Table 2. Serum biochemistry results from an external laboratory on the day of presentation.

\begin{tabular}{|c|c|c|}
\hline Parameter & Value & Reference Range \\
\hline Albumin/Globulin Ratio & 1.0 & $0.6-1.4$ \\
\hline Albumin $(\mathrm{g} / \mathrm{L})$ & 30 & $23-40$ \\
\hline $\begin{array}{l}\text { Alanine aminotransferase } \\
\text { (IU/L) }\end{array}$ & 97 & $16-90$ \\
\hline Amylase (IU/L) & 1056 & $333-1500$ \\
\hline Anion Gap (mmol/L) & 20.4 & $14.0-32.0$ \\
\hline $\begin{array}{l}\text { Aspartate aminotransferase } \\
\text { (IU/L) }\end{array}$ & 459 & $18-80$ \\
\hline Bicarbonate (mmol/L) & 19 & $12-26$ \\
\hline Calcium (mmol/L) & 2.0 & $1.9-2.9$ \\
\hline Calcium/Phosphate Ratio & 1.1 & \\
\hline Chloride (mmol/L) & 107 & $101-118$ \\
\hline Cholesterol (mmol/L) & 4.5 & $3.5-9.0$ \\
\hline Creatine kinase (IU/L) & 648 & $73-510$ \\
\hline Creatinine (mmol/L) & 0.08 & $0.05-0.13$ \\
\hline Globulin $(\mathrm{g} / \mathrm{L})$ & 31 & $25-45$ \\
\hline Glucose (mmol/L) & 4.7 & $3.3-6.8$ \\
\hline $\begin{array}{l}\text { Glucose fluoride oxalate } \\
(\mathrm{mmol} / \mathrm{L})\end{array}$ & 5.8 & $3.3-6.8$ \\
\hline Lipase (IU/L) & 196 & $77-750$ \\
\hline Sodium/Potassium Ratio & 42.1 & \\
\hline Phosphate (mmol/L) & 1.8 & $0.8-2.1$ \\
\hline Total bilirubin (umol/L) & $\begin{array}{l}\text { Below assay } \\
\text { linear range }\end{array}$ & $0-7$ \\
\hline Total protein $(\mathrm{g} / \mathrm{L})$ & 61 & $52-80$ \\
\hline $\begin{array}{l}\text { Alkaline phosphatase } \\
\text { (IU/L) }\end{array}$ & 139 & $1-150$ \\
\hline $\begin{array}{l}\text { Blood urea nitrogen } \\
(\mathrm{mmol} / \mathrm{L})\end{array}$ & 14.0 & $2.5-10.0$ \\
\hline $\begin{array}{l}\text { Gamma glutamyl } \\
\text { transferase (IU/L) }\end{array}$ & 0 & $0-9$ \\
\hline Potassium (mmol/L) & 3.4 & $3.9-5.9$ \\
\hline Sodium (mmol/L) & 143 & $139-153$ \\
\hline Thyroxine (nmol/L) & 10 & $13-52$ \\
\hline $\begin{array}{l}\text { Symmetric } \\
\text { dimethylarginine (ug/dL) }\end{array}$ & 3 & $0-14$ \\
\hline
\end{tabular}

There was a mild hypokalaemia and mildly increased sodium to potassium ratio. Total thyroxine was mildly decreased. Diagnostic imaging was not performed. The haematology results prompted encouragement of further anamnesis from the owners. They had been applying Sudocrem ${ }^{\circledR}$ to the dog's scalded skin five times daily for seven days, and had used an estimate of half of the $250 \mathrm{~g}$ container, or $125 \mathrm{~g}$. They often saw her with cream on her nose, and in hindsight, suspected she must have been ingesting it. This led to a presumptive diagnosis of zinc toxicosis. A serum zinc concentration was requested with the external laboratory. The zinc concentration returned three days post-discharge, and was markedly elevated at 237.1 $\mu \mathrm{mol} / \mathrm{L}$ (reference range $7-25 \mu \mathrm{mol} / \mathrm{L}$ ), confirming zinc toxicosis. 


\section{Treatment and outcome}

The dog received a $207 \mathrm{~mL}$ stored whole blood transfusion, and her haematocrit subsequently increased to $26 \%$. She was then treated with intravenous fluid therapy using Hartmann's solution with $20 \mathrm{mmol}$ potassium chloride, s-adenosyl methionine (SAMe) at $40 \mathrm{mg} / \mathrm{kg}$ initially followed by $20 \mathrm{mg} / \mathrm{kg}$ once daily, $150 \mathrm{mg}$ cephalexin twice daily, and $5 \mathrm{mg}$ prednisolone twice daily in case of an immune-mediated component to the anaemia. She responded rapidly to therapy and was discharged three days later.

Repeat haematology performed at the dog's family veterinarian a week later showed resolution of red cell abnormalities. Within a month of admission, the dog was clinically normal based on physical examination, and her owners considered her to have her normal demeanour and activity levels.

\section{Discussion}

The oral median lethal dose for zinc "salts" is reported as $100 \mathrm{mg} / \mathrm{kg}$ (Talcott, 2013). An estimated toxic dose of zinc oxide in dogs has been reported to be $108 \mathrm{~g}$ (Talcott, 2013). In the current case, the dog ingested an estimated maximum of $125 \mathrm{~g}$ of Sudocrem ${ }^{\circledR}$ over seven days. Sudocrem ${ }^{\circledR}$ contains $15.25 \%$ w/w zinc oxide. Thus, the dog could have ingested $386.4 \mathrm{mg} / \mathrm{kg}$ elemental zinc per day.

Zinc salts such as zinc oxide are relatively stable in the stomach (Talcott, 2013), whereas metallic zinc dissolves more rapidly in more acidic environments (Van Der Merwe and Tawde, 2009). This may be why zinc toxicosis is seen more commonly with ingestion of metallic objects. With acute zinc salt ingestion, there would be comparatively limited absorption of zinc in the gastrointestinal tract. Additionally, its gastric irritant effects often cause vomiting which prevents further absorption of zinc (Robinette, 1990; Welch, 2002). Presumably with chronic exposure, as occurred in the current case due to daily ingestion over approximately a week, there would be more time for zinc absorption to reach toxic concentrations.

In health, zinc has many important roles within the body and is required in more than 200 metalloenzymes (Cummings and Kovacic, 2009). It protects cellular membranes and thiol-dependent macromolecules against oxidative damage (Cummings and Kovacic, 2009). Zinc toxicosis, however, can cause severe disease, and commonly results in haemolytic anaemia. Its mechanism is still unknown. One hypothesis is that erythrocyte antioxidant pathways are inhibited leading to erythrocyte membrane oxidative damage (Cummings and Kovacic, 2009). Oxidative damage is associated with the formation of Heinz bodies. However, a case series of 19 dogs reported only $33 \%$ had Heinz bodies, suggesting other mechanisms may be involved (Gurnee and Drobatz, 2007). These include direct damage of red blood cells and hapten-induced immune destruction (Blundell and Adam, 2013).

In the current case, it was fortunate that Heinz bodies were present, as this prompted further anamnesis. The owners had been unaware of the potential adverse effects associated with the use of the zinc oxide cream, and only in hindsight realised the dog had potentially been ingesting large quantities.

The dog in the present case also displayed a moderate left-shift neutrophilia and moderate spherocytosis. Neutrophilia may result from non-specific bone marrow stimulation, or the release of cytokines by phagocytic cells (Bexfield et al., 2007). Spherocytosis occurs infrequently, with one study reporting it in $20 \%$ of 19 cases (Gurnee and Drobatz, 2007). Spherocytes are typically associated with immune-mediated haemolytic anaemia and this should still be suspected in animals with severe spherocytosis (Gurnee and Drobatz, 2007). A case of suspected zinc-induced secondary immune-mediated haemolytic anaemia has previously been reported (Cummings and Kovacic, 2009).

Zinc is absorbed from the intestines and transported to the liver, which regulates the body's metabolically active zinc pool (Cummings and Kovacic, 2009). From there, it is distributed, and accumulates in high concentrations in the pancreas, kidneys and spleen (Cummings and Kovacic, 2009; Talcott, 2013). Given this distribution, it is unsurprising that zinc toxicosis can lead to gastrointestinal dysfunction, hepatic dysfunction, renal failure, and pancreatitis or pancreatic fibrosis (Torrance and Fulton, 1987; Shaw et al., 1991; Gandini et al., 2002; Mikszewski et al., 2003; Hammond et al., 2004; Volmer et al., 2004; Gurnee and Drobatz, 2007; Weingart and Kohn, 2009; Blundell and Adam, 2013). Gastrointestinal disease appears most commonly caused by zinc's irritant and corrosive effects. (Blundell and Adam, 2013) Zinc may also have a direct toxic effect on renal and hepatic tissue (Gandini et al., 2002). Haemolysis also releases free haemoglobin, which is toxic to tissues (Gandini et al., 2002). Pancreatitis can occur secondary to excessive zinc accumulation, which damages pancreatic acinar cells causing release of digestive enzymes. Ischaemia and hypoxia secondary to haemolysis also contribute (Mikszewski et al., 2003).

In the present case, the dog had a mild elevation in aspartate aminotransferase with near-normal alanine aminotransferase. This suggests that the elevated aspartate aminotransferase was more likely from haemolysis or muscle hypoxia rather than hepatic disease (Gurnee and Drobatz, 2007). The dog also had an elevated activated partial thromboplastin time with normal prothrombin time.

Zinc is speculated to cause inhibition of coagulation factors VIII, IX, XI, and XII, which are part of the 
intrinsic coagulation cascade (Gurnee and Drobatz, 2007). Other common biochemical changes are elevations in urea, most likely from gastrointestinal haemorrhage, and hyperbilirubinaemia, most consistent with haemolysis (Gurnee and Drobatz, 2007).

Treatment of zinc toxicosis involves removal of the zinc source and supportive therapies, including blood transfusion, intravenous fluid therapy, gastroprotectants, anti-nausea medications, antioxidants, antibiotics, and sometimes chelation (Torrance and Fulton, 1987; Hammond et al., 2004; Gurnee and Drobatz, 2007; van der Merwe and Tawde, 2009; Talcott, 2013; Bischoff et al., 2017).

When a metallic zinc object is ingested, increasing gastric $\mathrm{pH}$ with antacids and gastroprotectants helps to reduce the rate of zinc dissolution until the object can be removed (van der Merwe and Tawde, 2009). Chelation with d-penicillamine or calcium sodium EDTA may be considered if zinc concentrations do not improve after removal of the zinc source (Lee et al., 2016).

Given the evidence of oxidative injury in the present case, SAMe was used for its antioxidant role. It is a precursor of glutathione, a major cellular antioxidant (Lu, 2000; Oz et al., 2005). SAMe has shown protection against oxidative stress in models of colitis, intestinal ischaemia, liver disorders, and even neurological disorders in humans (Lu, 2000; Oz et al., 2005; Camara-Lemarroy et al., 2011; Michael Brown et al., 2012; Au et al., 2013). In dogs, SAMe is hepatoprotective, and has been used as an alternative to $\mathrm{N}$-acetylcysteine in acetaminophen toxicity (Wallace $e t$ al., 2002; Au et al., 2013). To the author's knowledge, no studies have specifically examined the use of antioxidants in zinc toxicosis. It would be interesting to investigate their use in a clinical setting, particularly to determine their impact on recovery times and hospitalisation duration.

The prognosis for zinc toxicosis can be good depending on the severity of disease at the time of diagnosis. In a case series of 19 dogs, $89 \%$ survived to discharge and the median duration of hospitalisation was 2 days (Gurnee and Drobatz, 2007).

\section{Conclusions}

Zinc toxicosis is commonly associated with the ingestion of metallic objects, but can occur with ingestion of commonly available topical preparations. When prescribing treatments for animals, including over-the-counter medications, potential adverse effects should be discussed even if uncommon or unexpected. In cases of haemolytic anaemia, the medical history should rule out all potential toxicities. Zinc toxicosis can have a good prognosis with prompt recognition and treatment.

\section{Conflict of interest}

The authors declare that there is no conflict of interest.

\section{References}

Adam, F., Elliott, J., Dandrieux, J., German, A. and Blackwood, L. 2011. Zinc toxicity in two dogs associated with the ingestion of identification tags. Vet. Rec. 168, 84-85.

Au, A.Y., Hasenwinkel, J.M. and Frondoza, C.G. 2013. Hepatoprotective effects of S-adenosylmethionine and silybin on canine hepatocytes in vitro. J. Anim. Physiol. Anim. Nutr. (Berl), 97, 331-341.

Bexfield, N., Archer, J. and Herrtage, M. 2007. Heinz body haemolytic anaemia in a dog secondary to ingestion of a zinc toy: a case report. Vet. J. 174, 414-417.

Bischoff, K., Chiapella, A., Weisman, J., Crofton, L.M. and Hillebrandt, J. 2017. Zinc Toxicosis in a Boxer Dog Secondary to Ingestion of Holiday Garland. J. Med. Toxicol. 13, 263-266.

Blundell, R. and Adam, F. 2013. Haemolytic anaemia and acute pancreatitis associated with zinc toxicosis in a dog. Vet. Rec. 172, 17.

Borst, G.H., Peperkamp, N.H. and Soethout, N.C. 2004. [Acute zinc poisoning in a dog]. Tijdschr. Diergeneeskd. 129, 676-677.

Camara-Lemarroy, C.R., Guzman-De La Garza, F.J., Cordero-Perez, P., Alarcon-Galvan, G., TorresGonzalez, L., Munoz-Espinosa, L.E. and Fernandez-Garza, N.E. 2011. Comparative effects of triflusal, S-adenosylmethionine, and dextromethorphan over intestinal ischemia/reperfusion injury. Sci. World J. 11, 18861892.

Clancey, N.P. and Murphy, M.C. 2012. Zinc-induced hemolytic anemia in a dog caused by ingestion of a game-playing die. Can. Vet. J. 53, 383-386.

Cummings, J.E. and Kovacic, J.P. 2009. The ubiquitous role of zinc in health and disease. J. Vet. Emerg. Crit. Care (San Antonio), 19, 215-240.

Gandini, G., Bettini, G., Pietra, M., Mandrioli, L. and Carpene, E. 2002. Clinical and pathological findings of acute zinc intoxication in a puppy. $J$. Small Anim. Pract. 43, 539-542.

Gurnee, C.M. and Drobatz, K.J. 2007. Zinc intoxication in dogs: 19 cases (1991-2003). J. Am. Vet. Med. Assoc. 230, 1174-1179.

Hammond, G.M., Loewen, M.E. and Blakley, B.R. 2004. Diagnosis and treatment of zinc poisoning in a dog. Vet. Hum. Toxicol. 46, 272-275.

Inns, J.H. 1995. Zinc toxicity in a dog following ingestion of zinc-oxide and calamine. Aust. Vet. Pract. 25, 118-121.

Latimer, K.S., Jain, A.V., Inglesby, H.B., Clarkson, W.D. and Johnson, G.B. 1989. Zinc-induced hemolytic anemia caused by ingestion of pennies by a pup. J. Am. Vet. Med. Assoc. 195, 77-80.

Lee, Y.R., Kang, M.H. and Park, H.M. 2016. Treatment of zinc toxicosis in a dog with chelation using d- 
penicillamine. J. Vet. Emerg. Crit. Care (San Antonio), 26, 825-830.

Lu, S.C. 2000. S-Adenosylmethionine. Int. J. Biochem. Cell Biol. 32, 391-395.

Luttgen, P.J., Whitney, M.S., Wolf, A.M. and Scruggs, D.W. 1990. Heinz body hemolytic anemia associated with high plasma zinc concentration in a dog. J. Am. Vet. Med. Assoc. 197, 1347-1350.

Michael Brown, J., Ball, J.G., Wright, M.S., Van Meter, S. and Valentovic, M.A. 2012. Novel protective mechanisms for S-adenosyl-Lmethionine against acetaminophen hepatotoxicity: improvement of key antioxidant enzymatic function. Toxicol. Lett. 212, 320-328.

Mikszewski, J.S., Saunders, H.M. and Hess, R.S. 2003. Zinc-associated acute pancreatitis in a dog. J. Small Anim. Pract. 44, 177-180.

Norman, A., Spencer, C.P., Sundlof, S.F. and Partridge, H.L. 1990. Zinc toxicosis in a dog secondary to ingestion of pennies. Vet. Radiol. Ultrasound. 31, 155-157.

Oz, H.S., Chen, T.S., McClain, C.J. and De Villiers, W.J. 2005. Antioxidants as novel therapy in a murine model of colitis. J. Nutr. Biochem. 16, 297304.

Robinette, C.L. 1990. Toxicology of selected pesticides, drugs, and chemicals. Zinc. Vet. Clin.
North Am. Small Anim. Pract. 20, 539-544.

Shaw, D.P., Collins, J.E. and Murphy, M.J. 1991. Pancreatic fibrosis associated with zinc toxicosis in a dog. J. Vet. Diagn. Invest. 3, 80-81.

Talcott, P.A. 2013. Zinc. In: Peterson, M.E. and Talcott, P.A. (eds.) Small Animal Toxicology. $3^{\text {rd }}$ ed. St Louis, Missouri: Elsevier Saunders.

Torrance, A.G. and Fulton, R.B., JR. 1987. Zincinduced hemolytic anemia in a dog. J. Am. Vet. Med. Assoc. 191, 443-4.

Van Der Merwe, D. and Tawde, S. 2009. Antacids in the initial management of metallic zinc ingestion in dogs. J. Vet. Pharmacol. Ther. 32, 203-206.

Volmer, P.A., Roberts, J. and Meerdink, G.L. 2004. Anuric renal failure associated with zinc toxicosis in a dog. Vet. Hum. Toxicol. 46, 276-278.

Wallace, K.P., Center, S.A., Hickford, F.H., Warner, K.L. and Smith, S. 2002. S-adenosyl-L-methionine (SAMe) for the treatment of acetaminophen toxicity in a dog. J. Am. Anim. Hosp. Assoc. 38(3), 246254.

Weingart, C. and Kohn, B. 2009. [Zinc intoxication in a Yorkshire Terrier due to Euro cent ingestion]. Schweiz. Arch. Tierheilkd. 151, 75-81.

Welch, S.L. 2002. Oral toxicity of topical preparations. Vet. Clin. North Am. Small Anim. Pract. 32, 443453, vii. 